\title{
PRECINCTS OF CONTENTION: URBAN PLACES AND THE IDEOLOGY OF SPACE IN CELESTINA
}

\author{
E. Michael Gerli \\ Georgetown University
}

For Louise, a gracious and witty friend

Celestina is the first work of early Spanish literature to portray urban spaces in any concerted fashion. Through the complex manipulation of dialogue, descriptions of locations and settings are almost imperceptively embedded in the characters' speeches and become integral parts of the narrative fabric of the work, complements of what the characters do, say, and believe (on narrative inlaying see Lida de Malkiel 81-107). As Stephen Gilman notes in his masterful study of Celestina, the representation of material space is a decisive component of the work's verbal art. The dialogue takes the reader "a través de una estructura de acaeceres radicalmente espacial, sucediéndose en constante progresión cinematográfica: dentro, fuera, adelante, abajo, arriba, hacia atrás, a través de iglesias, escaleras arriba, al interior de los jardines .... del comienzo al fin de la obra. Y cuando surgen obstáculos (muro, puertas, etc.), lo son en efecto para los deseos de los personajes y no simple decorado o mero juego de detalle escénico. Esta libertad espacial es la que, mejor que ningún otro rasgo, produce en nosotros esa ilusión engañosa de realidad identificable en la ficticia ciudad de La Celestina" (368).

Several critics have pursued Gilman's astute observations. George Shipley, for one, has explored an essential irony of place in Celestina, showing how the spatial imagery comprising Melibea's garden mimics the locus amoenus of the medieval amatory tradition and how it is verbally and situationally undermined to produce in the reader "complex and tense reactions which can properly be called disconcerting" (287). This is accomplished through the violation of the artistic protocols of the 
garden motif and the decentering of its commonplaces, resulting in a sense of incongruity and displacement toward the unknown. Similarly, expanding upon Gilman's commentary concerning the figurative role played by locations in Celestina, Deborah Ellis has focused on the symbolic value of the home and finds in the work's conflictive portrayal of domestic sites a meta-representational likeness of a psychic alienation that pervades the text-a portrayal of "a world whose limits are disappearing and whose order is overturned, " a depiction whose imagery bespeaks "insecurity and destruction" (15). Finally, Erna Berndt Kelley and Isidro Rivera have examined the way in which the work's verbal evocation of place was visualized by the artists who composed the woodcuts in the oldest known printing of Celestina.

That there is space in Celestina, that there are visualized places, is not a disinterested fact or a routine convention, but a significant occurrence that points to the presence of ideas and convictions in the text. As linguistic constructs, imagined sites in Celestina are much more than straightforward renderings of place. Rather, they constitute representations: verbally constructed interpretations of the physical world implicated in a broad network of concepts, sense, and connotation. The visualization of space, as Gaston Bachelard observes, always carries with it an implicit ideological and phenomenological significance: when we imagine spaces and scan locations, places, and rooms we generally "read" those sites for the values vested in them, seeking the relevance they embrace for us and for the individuals who inhabit them (14; see Tuan and Lutwack also).

Similarly, Peter Stallybrass and Allon White note that "space is never completely independent of social place" and that "the formation of new kinds of speech can be traced through the emergence of new sites of discourse and the transformation of the old ones." Each real or imagined site, they say, "constitutes a nucleus of material and cultural conditions which regulate what may and may not be said, who may speak, how people may communicate and what importance must be given to what is said" (80). Utterances may thus be legitimized or dismissed according to the place where they are produced, while the history of social and political struggle can be seen as the chronicle of attempts to command significant sites and spaces of communication. In short, locations may prompt, sanction, and promote, as well as inhibit, certain kinds of actions, thoughts, and speech, and they may be approached as correlatives of ideology, which can be revealed by examining "the relation between an utterance and its material conditions 
of possibility" (Eagleton, Ideology, 223). ${ }^{1}$ In this way, the representation of physical space comprises a significant extension of the domains of discourse and signification. The verbal portrayal of location fits into a larger scheme that forms part of an organized semiotic system which conveys sense upon both language and its material whereabouts.

Celestina is filled with dialogues that unfold in specific, verbally constructed, three-dimensional spaces, just as it is fraught with oblique descriptions of the city in which it transpires and the money-making activities that occur there. Quite in passing, for example, an exchange between minor characters (Sosia and Tristán in Auto XIV) may inform us that tradesmen of every sort eager to work awaken at dawn to go to their shops along the narrow streets to the center of town: merchants, carpenters, blacksmiths, farriers, gardeners, and weavers alike all set forth, "cobdiciosos de temporales bienes" (287), evoking the bustling economic life of the city. Similarly, all manner of professionals (doctors, lawyers, judges, and bailiffs) practice their craft near the urban sites through which the characters pass. In the early morning on the outskirts of the town, too, "suelen levantarse ... los trabajadores de los campos y labranças, y los pastores ... [y] en este tiempo traen las, ovejas a estos apriscos a ordeñar" (287). Everywhere the characters turn, beyond their immediate conversation there is a sense of inhabited room teeming with purposeful activity. More than a barren stage for the drama of love and death which unfolds in the work, the imagined city in which Celestina transpires is a thriving locale resonating with noises, voices and every kind of enterprise- a flourishing center of both legitimate and illicit talk and commerce.

Celestina and her confederates, for example, are identified as creatures of the street. On more than one occasion we follow them in their dialogue as they walk to and from Calisto's, Celestina's, and Melibea's houses. However, the streets they traverse are described less for their value as empirical points on a map than as scenarios of conspiracy and perilous precincts of violent social and economic plunder. As they perambulate through them, Sempronio and Celestina plan

\footnotetext{
${ }^{1}$ I use the word "ideology" in terms of the connection between discourse and power. Eagleton notes that "Discourses, sign-systems and signifying practices of all kinds (...) produce effects, shape forms of consciousness and unconsciousness, which are closely related to the maintenance or transformation of our existing systems of power (...) 'ideology' can be taken to indicate no more than this connection-the link or nexus between discourses and power" (Literary Theory 210).
} 
Calisto's despoilment; and Celestina when ambling alone pleads for the Devil's intercession in her plan. At night, she tells us, those same streets become civic battlegrounds lurking with danger, where the anonymous citizens who pass through them are both victims and perpetrators of violent crimes. Obliged by prudence to walk at night down the middle of the lane, Celestina informs. Elicia "que jamás me subo por poyo ni calçada sino por medio de la calle. Porque como dizen, no da passo seguro quien corre por el muro, y que aquel va más sano que anda por el llano. Más quiero ensuziar mis çapatos con el lodo que ensangrentar las tocas y los cantos" (254). The potential of robbery, rape and plunder lurks around every corner and every dark doorway in this imagined city. During her nocturnal wanderings, Celestina can only find solace in the fact that her advanced age and worn condition will save her from becoming a target of urban aggression.

The creation of spaces and locations in Celestina is, then, both substantial and complex. In addition to the psychological and ironical manifestations outlined by Gilman, Ellis, and Shipley it often involves a series of presuppositions concerning the nature of human social, political, and economic activity. Issues of class and authority are linked to wealth, ownership, and the control of property, reflecting the cultural and historical developments taking place at the end of the fifteenth century. As Maravall has shown, the economic transformations of the period led to the disintegration of the traditional paternalistic organizational structures of society and to the creation of a radical sense of acquisitive individualism. The equation of space and property with power and personal identity in Celestina - the image of affluence and place as the visible domains of agency-provide the nucleus for the work's social and ethical confrontations. Landscape and architecture in it contribute to the mapping of ideological realms that give form and value to human attitudes about class status and society not yet articulated in a consciously systematic fashion. In a time when Spain had embarked on an extended conquest and colonization of the world, the visualization of the relationship between human subjects and physical spaces, property, and wealth emerges explicitly in Celestina and may be seen in terms of a politics of domination-the control of the inhabitants of one locale by those of another.

The representations of certain types of sites in Celestina are 'enmeshed in the contest for power, the justification of the ownership of property, and the construction of the human subject. This is clear, for example, in the depiction of Celestina's and Areúsa's houses. The latter, shunning the humiliation of domestic servitude in the dwellings of the rich, prefers to be a prostitute and "bivir en mi pequeña casa esenta y 
señora, que no en sus ricos palacios sojuzgada y cativa" (233). In this way, prostitution in Celestina becomes a means not so much for wealth itself but for the recovery of a place of sanctuary and repose for the plebeian subject, an activity whose end affords the acquisition of a sense of autonomy, privacy, and personal space.

Ironically, then, Celestina's and Areúsa's houses are also imagined as their homes, places of shelter, respite, and comfort as well as emporiums of sexual commerce, witchcraft, and carnal industry. Their abodes form an integral part of a larger system that endows property and wealth with animating attributes-with individual meaning-and accounts for their roles as personal motivators in the text. Yet despite the yearnings of the inhabitants of these houses, privacy and abundance in the domestic economy of their homes may only be had at the expense of transgression-of harlotry, theft, and peculation since, as we learn, the money that pays the rent, and the food that fills the table at Celestina's banquet, must be filched from the likes of Calisto and Pleberio (218). The complex image of Celestina's house, invoked first with the concision of a proverb, is used to express a sense of ownership, group solidarity, and a radical insouciance at the thought of ill-gotten wealth. Her house (or "our house," as she invokes it to overcome Pármeno's initial resistance) stands as an arresting image of both group identity and unprincipled ambition. To Pármeno's objection that "no querría bienes mal ganados" she retorts, "Yo sí. A tuerto o a derecho, nuestra casa hasta el techo" (123).

The verbal description of Celestina's house itself invites the reader not merely to imagine the structure, but to formulate it as an expression of an idea: a desire suffused with both personal and political significance. In addition to a brothel, it is, as Alison Weber remarks, envisioned by the servants as a "utopian alternative to the master's house/prison:" as a "place of peace and rest, rather than enforced labor; a hospital of maternal care rather than emotional neglect; a purse of plenty rather than deprivation; a strongbox of financial security rather than economic instability. It is a place where homosocial bonds complement heterosexual fulfillment" (133). Celestina's abode stands as a monument to the craving for personal empowerment through the ownership and dominion of possessions-as a fantasy of stability and legitimacy that lies at the center of proletarian illusions. Its dining room, a figurative extension of these ideas, must be read as a spatial image of the hunger for personal gratification and the resolution of social and historical contradictions. To be sure, it is in Celestina's egalitarian refectory that, in the heat of partisan debate concerning the value of the rich, characters like Areúsa loudly reject the notion of a privileged class defined by 
genealogy: "Ruyn sea quien por ruyn se tiene," she exclaims, "las obras hazen linaje, que al fin todos somos hijos de Adam y Eva. Procure de ser cada uno bueno por sí, y no vaya a buscar en la nobleza de sus passados la virtud" (229). It is there, too, that as a former domestic servant she boisterously illustrates how servitude in patrician dwellings thwarts privacy, pleasure, friendship, and ultimately a sense of self:

éstas que sirven a señoras ni gozan deleyte ni conocen los dulces premios del amor. Nunca tratan con parientas, con yguales a qien pueden hablar tú por tú, con quien digan "¿qué cenaste?; estás preñada?; quántas gallinas crías?; llévame a merendar a tu casa; muéstrame tu enamorado; ¿quánto ha que no te vido?; ¿cómo te va con él?; quién son tus vezinas?" y otras cosas de ygualdad semejantes. ¡O tía, y qué duro nombre y qué grave y sobervio es "señora" contino en la boca. Por esto me bivo sobre mí, desde que me sé conoscer, que jamás me precié de llamar de otrie sino mía. (232)

Celestina's abode becomes a site which reminds us that, although the servants who congregate there may be economically reliant on Calisto's and Pleberio's households, they refuse to view themselves as socially and psychologically dependent on them. In the politically transgressive speech they give vent to at Celestina's house, they strive to challenge and dispute the system of exchange which governs them and imposes limits on their place in the world. Celestina's residence exists, then, as a spot that, in addition to offering rest and reassurance, provides a provisionally controlled space which sanctions the freedom to imagine and publicly utter dissident thoughts. At the same time, too, it becomes the explicit scenario for the expression of what Fredric Jameson has termed "commodity lust" (159), or the articulation of longings for wealth, property, and prosperity through the evocation of material things.

The bounteous description of the victuals that fill Celestina's dining room represents them not simply as food but as social signifiers-as a revery of plenty imagined from a position of lack. More than a simple inventory, the edible objects that spill over onto Celestina's table fill out a symbolic space and constitute an image of coveted opulence which reflects the condition of those who do not regularly enjoy it. The "pollos, y gallinas, anserones, anadones, perdizes, tórtolas, perniles de toçino, tortas de trigo, lechones," and the wines "de Monviedro, de Luque, de Toro, de Madrigal, de San Martín, y de otros muchos lugares" (236) overwhelm the regions of the social imagination just as the real objects they signify once, at the height her prosperity, 
engulfed the old bawd's dining room. The praise of plenty that reverberates at Celestina's table marks a sense of constitutional deficiency, a deprivation of empowerment which energizes the characters' motor of transgression.

Although always open to the street (225), Celestina's house is portrayed as a secure, enclosed space, a setting for three types of concealed activities: bartered sex, the consumption of pilfered food, and most meaningfully underground partisan debate centering on the perquisites of wealth and status. It is the latter enterprise, of course, which gives symbolic meaning to the two former activities, providing the basic rationale for their existence in the work. More than the sexual friction under the table, the social friction expounded at table places into perspective the contentious and civilly transgressive nature of the servants' hunger and sexuality. Motivated by appetites of the social imagination rather than of the body, it is made clear in the intimacy of Celestina's house that caste difference and a sense of constitutional lack stand at the center of the servants' drives.

The old bawd's house comprises the central place where all the "marginal" characters in the work converge, a collective expression of their desire for sanctuary as well as the social alienation and disorder around which all the events in the work turn. The craftsmen who created the woodcuts for the earliest edition of Celestina clearly understood this and represented its space as an expression of the yearning for material comfort, freedom of movement, and sociability. The neatly draped banquet table they portray appears with food in the background of their substantial interpretation of the dwelling, whose populated doorway is open to the comings and goings of the street.

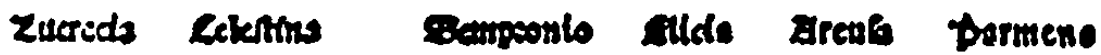

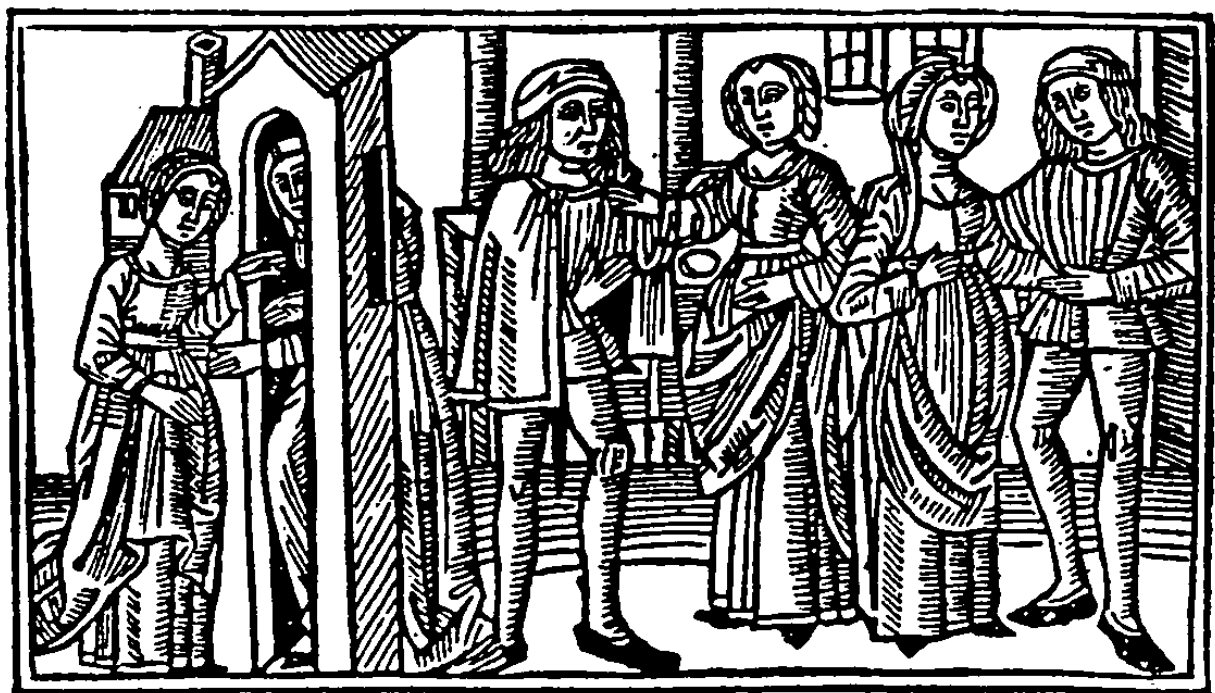


Linguistic and visual images converge in the woodcuts of the earliest Celestina to reveal an awareness of the subtle significances of the spatial matrices evoked in the characters' dialogue and embedded in the oblique descriptions of their environment.

To be sure, even the physical location of Celestina's house constitutes a complement to a larger figurative significance. Two recent studies (Russell, Lacarra) have dwelled on the fact that the text pointedly situates Celestina's house in separate locations: prior to the action it had been in Pleberio's neighborhood; but now, as events transpire, it is located "cerca de la tenerias," by the river on the outskirts of town according to Pármeno (110). While this may reflect an actual historical occurrence, as Lacarra and Russell assert, the peripheral location of Celestina's house may also be viewed in terms of the social stratification expressed through the spatial segregation of classes which began to appear in cities at the end of the fifteenth century.

As municipalities began to grow, urban development was characterized by the dispersal and distribution of the population into neighborhoods defined strictly along socio-economic lines. The lower classes were gradually moved out from the center to the fringes of town (Ackerman and Rosenfeld). Viewed from the perspective of Renaissance urban transformations, Celestina's move doubtless harbors more than historical detail: it is charged with symbolic value, expressive of the fact that the old mixed community of the medieval city has been economically and socially segregated and now remains spatially divided. Indeed, Celestina did not just move house: she was compelled to do so by community forces which sought to isolate not just prostitutes and beggars but all the other members of the lower classes. Separate and marginalized, conspicuously obliged to relocate to the geographical as well as social perimeter of power, her new abode at the edge of town accentuates her increasingly peripheral civic position as well as her desire for wealth as a means of enfranchisement.

In stark contrast to Celestina's plebeian dwelling, Pleberio's domus stands at the center of the town and incorporates the traditional symbolic elements of aristocratic discourse, architectural components we associate with power and the patriarchal world of courtly texts: the tower, a beautiful maiden, an enclosed garden, and the walls which isolate it from an encroaching world. A secure, almost fortified structure with multiple doors (entrances with antepuertas 239), its imagery is vertical and constitutes a closed place above, as well as apart, from the fray-a space which keeps its back to society. Yet it is a space with other than aristocratic intimations: it is expressive of unease, suffused with 
apprehension, a house filled with vigilant, anxious inhabitants who startle at the slightest sound as they stand watch over its human capital, Melibea ("¿No oyes bullicio en el retraymiento de tu hija?" 266). The wariness of its inhabitants contradicts the images of consummate power and control we traditionally associate with privileged settings. The interiors of Pleberio's mansion remain cloistered from the world around it, yet they are vulnerable to desire. Entry there is tightly regulated and is both difficult and protected; those who live in it remain ever watchful of trespass. Defended from intrusion by physical barriers which stand as metaphors of social as well as sexual segregation, the space encompassing Pleberio's house can only be accessed by furtive means-literally breaching its walls - even by those who claim to be its master's equals (Calisto).

Resting at the center of Pleberio's mansion is his most guarded possession, Melibea, who is repeatedly characterized as an extension of the contained universe she inhabits. She is an "encerrada doncella" (238, 245) an image which more than describe her condition valorizes Pleberio's concern for. his family's high status and unblemished genealogy. The house which impounds Melibea is constituted as a symbolic representation of Pleberio's exclusionary social and familial practices, as the concrete correlative of his claim to a patrician identity.

Yet that identity is challenged by Calisto, Celestina and the servants, broken down through the literal breaching of the walls which symbolize it, culminating, as remains to be seen, in spatial images of the final scene. It is for this reason that Theresa Ann Sears remarks that "In perhaps no other literary work are more walls-real and figurative-leveled than in Fernando de Rojas' Celestina" (95). The incursion into Pleberio's physical space negotiated by Celestina and her confederates constitutes the disintegration of the illusionary walls of class and identity erected by Pleberio to keep the two worlds apart.

The final scenes depicting physical spaces in Celestina function as ironic counterpoints to the social contest depicted in the work. The proverbial enclosed garden rather than the setting for life, love, and exuberance is rapidly transformed into a place of rupture, grief, and death. To be sure, even Melibea's suicide is symbolically portrayed as a final gesture of enclosure: "Quiero cerrar la puerta, por que ninguno suba a me estorvar mi muerte" (331) she says as she secures the door to the tower from which she leaps to her extinction. Moreover, although the tower in Pleberio's garden opens up onto the horizon, the landscape before it symbolizes mourning, called forth to be observed only after Melibea hurtles to her death. Pleberio's verbal circumscription of the land 
beyond the confines of his garden is a gesture that seeks to claim the outside world: the inventory of ships, trees, and towers he invokes in his valedictory (337) are objects on the landscape that are simultaneously his but now devoid of purpose. And still, in his most calamitous moment, the description of place and setting carries with it the freight of class interest in controlled property. The broad vista incorporates the horizon as a metaphor of affluence and power-an image suggestive of a mercantile, colonial ideology. Yet it is now distant, inaccessible and unmoving. "The real estate endures, for reasons Pleberio cannot understand," remarks Shipley (299). It remains as a bitter reminder of his personal helplessness despite his earlier ability to acquire and control the physical universe. Pleberio's urge to create and command space, the aspiration to encompass and master the visible world is, in macabre fashion, foreshortened in Melibea's steep drop from the tower.

The landscape that the eye captures, cluttered with the owned objects Pleberio invokes, is suddenly and dramatically compressed: the notion that ownership and power are interchangeable topples down symbolically along with his daughter. The exchange values of property and mastery are, in the end, denied. The fixed system of meaning assigned to dominion and wealth shatters as it is spatially represented as something which, though belonging to Pleberio, is radically disconnected from him at the moment of his greatest vulnerability. It is as if at the close of Celestina, power and the space it affords remain inscribed in a new domain: the realm of impotence. Melibea's self-inflicted end guarantees an end to her father's line and an end to his authority: it quite literally signifies the Fall of the House of Pleberio.

In ironic contrast to the fate of Pleberio's domus after the death of Melibea, Celestina's house, inherited by Elicia ("jamás perderá aquella casa el nombre de Celestina" 300), encompasses continuity and constitutes an assurance that the old bawd's world, though she is dead and gone, is guaranteed succession (Deyermond 17-18). There is a sensation of vitality and progression in this image that contrasts dramatically with the feeling of both spatial and existential enclosure developed in the final scene at the foot of Pleberio's tower.

Both Pleberio's and Celestina's houses constitute crucial signs which help define the world in which the characters move. They operate as indispensable parts of the total system of representation in Celestina, a pattern of spatial imagery designed to convey messages to the readers outside the text about the inhabitants in it. As such, these domains possess a metonymic relation to the central ideological themeș which 
comprise the work. The depiction of space in Celestina marks a decisive development in the representation of the human subject in late fifteenthcentury texts: it becomes the depository of desires, the material field that stands as an emblem of the characters' identities and ambitions. A fetishizing of the material world is now clearly connected to the process of socially defining the individual.

Celestina offers a prime example of the fact that the appropriation of the physical world serves as a cornerstone of early modern ideology: sites in it acquire constitutive power for the subjects who occupy them; and the latter are constructed and reconstructed not only by how but also by where they live and the property they own. Put simply, inhabiting owned property becomes a significant gesture of personal and social identity in the work. Location in it is thus infused with significance and often functions, more than as mere setting, as the battleground for depicting a larger social drama. The places that pretend to be embodiments of the real are in fact encampments of conviction, nothing less than correlatives of the work's social anxieties and thematic contentions.

While it is a truism that as readers and critics we tend often to fall into the historicist fallacy that locations in literary works correspond to actual topography, the Salamanca of Fernando de Rojas (pace Russell; Severin and Snow) is clearly no more Salamanca than the one depicted in Lazarillo de Tormes. Rather Celestina's Salamanca serves an ideational function and should not be confused with a concrete site. Its main purpose is not to mark ontological distinctions of geography but to signal social ones-to embody messages about the structures of power in the world in which the characters live. The way it does this is inevitably significant. Places and spaces in Celestina are not renderings of the real but sites crisscrossed by conflicting forces of representation. As a response to the unidirectional flow of meaning and identity proposed by an aristocratic, patriarchal world Celestina announces the existence of a counterdiscourse of identity cast in the figurative possibilities of location and desire. Ultimately, the problematic representation of space in it poses serious questions regarding the relationship between art and politics in late fifteenth-century Spain and between individuals and the fetishized material universe in which they were beginning to move. 


\section{WORKS CITED}

ACKERMAN, James S., and Myra N. ROSENFELD. "Social Stratification in Renaissance Urban Planning." In Urban Life in the Renaissance. Ed. Susan Zimmerman and Ronald E. Weissman. Newark, DE: University of Delaware Press, 1989. 21-49.

BACHELARD, Gaston. The Poetics of Space. Trans. Maria Jolas. Boston: Beacon Press, 1994.

BERNDT KELLEY, Erna R. "Mute Commentaries on a Text: The Illustrations of the Comedia de Calisto y Melibea." In Fernando de Rojas and Celestina: Approaching the Fifth Century. Ed. Ivy Corfis \& Joseph T. Snow. Madison: HSMS, 1993. 193-227.

DEYERMOND, Alan. "Female Societies in Celestina." In Fernando de Rojas and Celestina. Ed. Ivy A. Corfis and Joseph T. Snow. Madison: HSMS, 1993. 1-31.

EAGLETON, Terry. Ideology: An Introduction. London: Verso, 1991. Literary Theory. Minneapolis: University of Minnesota Press, 1983.

ELLIS, Deborah. "'AAdiós paredes!': The Image of the Home in Celestina." Celestinesca 5.2 (1981): 1-17.

GILMAN, Stephen. La Celestina: Arte y estructura. Trad. Margit Frenk de Alatorre. Madrid: Taurus, 1974.

JAMESON, Fredric. The Political Unconscious: Narrative as a Socially Symbolic Act. Ithaca: Cornell, UP, 1981.

LACARRA, María Eugenia. "La evolución de la prostitución en la Castilla del siglo XV y la mancebía de Salamanca en los tiempos de Fernando de Rojas." In Fernando de Rojas and 'Celestina': Approaching the Fifth Centenary. Ed. Ivy A. Corfis \& Joseph T. Snow. Madison: HSMS, 1993. 33-78.

LIDA DE MALKIEL, María Rosa. La originaldad artística de La Celestina. 2nd ed. Buenos Aires: EUDEBA, 1970.

LUTWACK, Leonard. The Role of Place in Literature. Syracuse, NY: Syracuse UP, 1984.

MARAVALL, José Antonio. El mundo social de La Celestina. $2^{\mathrm{a}}$ ed. Madrid: Gredos, 1968.

RIVERA, Isidro J. "Visual Structures and Verbal Representation in the Comedia de Calisto y Melibea (Burgos, 1499?)." Celestinesca 19 (1995): 3-30.

ROJAS, Fernando de. La Celestina. Ed. Dorothy S. Severin. Madrid: Cátedra, 1987.

RUSSELL, P.E. "Why did Celestina Move House?" In The Age of the Catholic Monarchs, 1474-1516. Literary Studies in Memory of Keith Whinnom. Ed. Alan Deyermond \& Ian Macpherson. Liverpool: Liverpool. UP, 1989. 155-61. 
SEARS, Theresa Ann. "Love and the Lure of Chaos: Difference and Disorder in Celestina." Romanic Review 83 (1992): 94-106.

SEVERIN, Dorothy S., and Joseph T. SNOW. "La casa de Pleberio en Salamanca." Celestinesca 12.1 (1988): 55-58.

SHIPLEY, George. "Non erat hic locus; the Disconcerted Reader in Melibea's Garden." Romance Philology 27 (1973-74): 286-303.

STALLYBRASS, Peter \& Allon WHITE. The Politics and Poetics of Transgression. London: Methuen, 1986.

TUAN, Yi-Fu. Topophilia: A Study of Environmental Perception, Attitudes, and Values. Englewood Cliffs, NJ: Prentice-Hall, 1974.

WEBER, Alison. "Celestina and the Discourses of Servitude." In Negotiating Past and Present: Studies in Spanish Literature for Javier Herrero. Ed. David T. Gies. Charlottesville: Rockwood Press, 1997. 127-144.
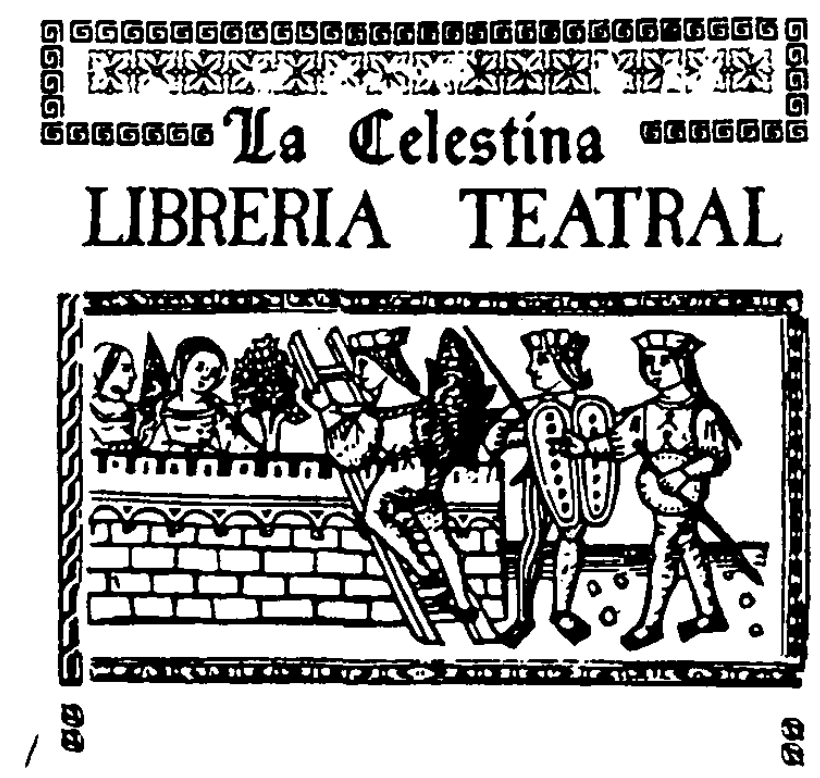

Huenas, 21 - Tel. 4290015 - 28014 Madrid 


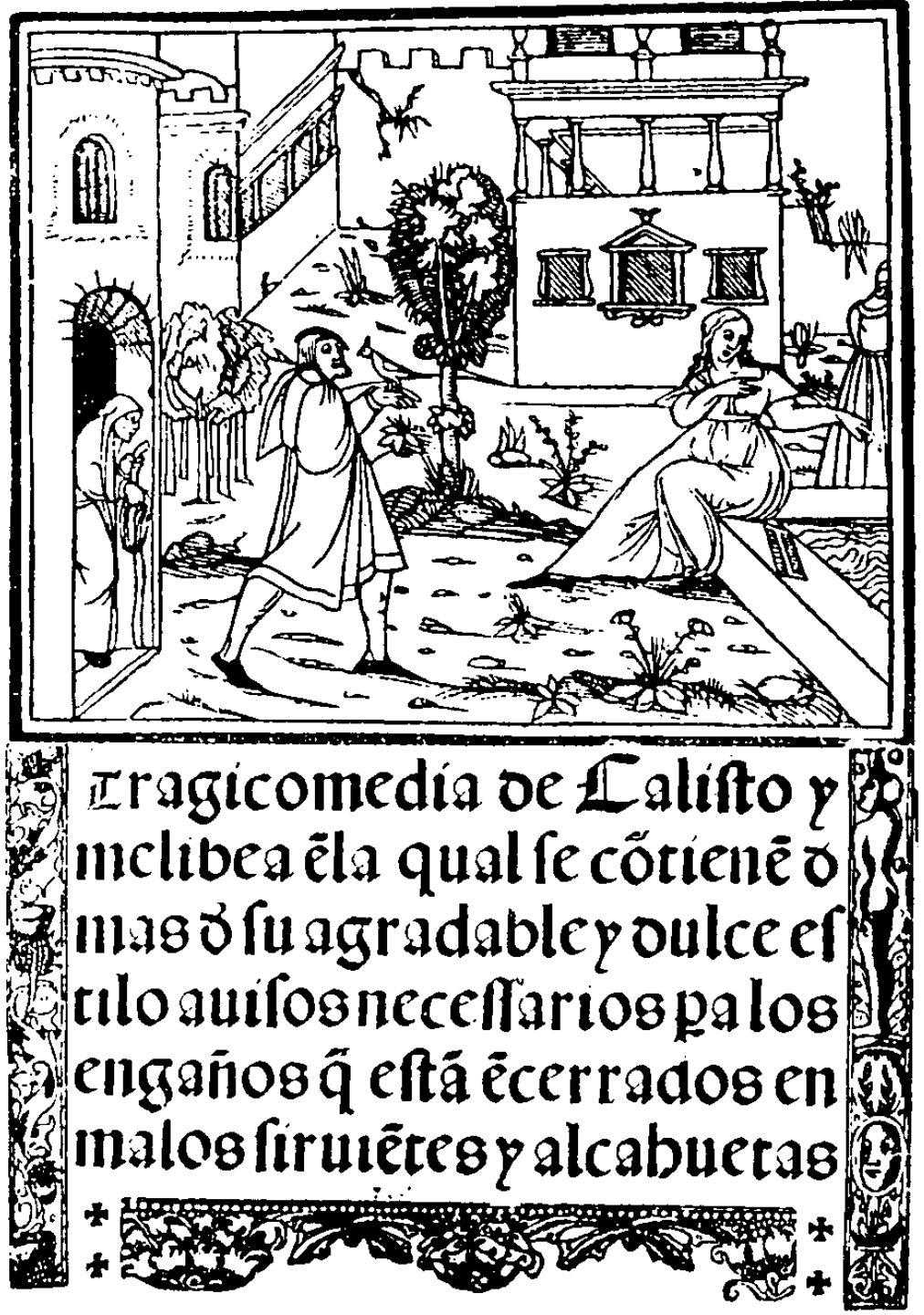

Lisboa, Ed. Luis Rodrigues, 1540. Portada. 